\title{
Analisis Kinerja Guru Pendidikan Kewarganegaraan dalam Membina Karakter Etika Pergaulan dan Moral Siswa SMPN 5 Lembar
}

\author{
Hafsah1, Yuhri Fulmiyati²
}

\begin{abstract}
1Pendidikan Pancasila dan Kewarganegaraan, Universitas Muhammadiyah Mataram,Email: dansa_machi@yahoo.co.id 2Pendidikan Pancasila dan Kewarganegaraan, Universitas Muhammadiyah Mataram, Email: yuhrifulmiyati069@gmail.com
\end{abstract}

\begin{abstract}
INFO ARTIKEL
Riwayat Artikel:

Diterima: 20-Agustus2019

Disetujui: 26-September2019
\end{abstract}

\section{Kata Kunci:}

Kinerja Guru

Pendidikan

Kewarganegaraan

Membina Etika

Moral Siswa

\section{ABSTRAK}

\begin{abstract}
Abstrak: Bangsa yang bijak harus berpikir cerdas untuk jangka panjang bahwa pemegang tongkat estafet bangsa ini adalah anak-anak muda sebagai generasi penerus bangsa. Permasalahan etika dan moral anak bangsa menjadi permasalahan yang sangat mendasar dinegeri ini. Mengatasinya melalui pendidikan melalui orang tua, guru lingkungan sekitar. Penelitian ini bertujuan mendeskripsikan kinerja Guru Pendidikar Kewarganegaraan dalam Membina Karakter Etika Pergaulan dan Moral Siswa di SMPN 5 Lembar Lombok Barat. Jenis penelitian yang digunakan adalah penelitian kualitati dengan pendekatan deskriptif. Subjek penelitian yaitu guru PPKn, siswa kelas VII kepala sekolah, dan guru BK. Metode pengumpulan data yang digunakan ini adalah metode observasi, dokumentasi, dan wawancara yang terstruktur. Tehnik analisis data yang digunakan adalah deskriptif kualitatif melalui reduksi data, penyajian data, dan penarikan kesimpulan. Hasil penelitian menunjukkan bahwa kinerja guru pendidikar. kewarganegaraan dalam membina etika dan moral siswa kelas VII di SMP Negeri 5 Lembar terbagi menjadi empat tahapan yaitu kesiapan guru, penerapan mode] pembelajaran kurikulum K-13, melakukan kerjasama dengan orang tua, dan memberikan pembelajaran spiritual keagamaan melaui imtak dan sholat duha. Dan faktor yang mempengaruhi kinerja guru dalam membina etika dan moral siswa kelas VI] di SMP Negeri 5 Lembar yaitu faktor pendukung, faktor sikap siswa, faktor keluarga faktor lingkungan, dan faktor lainnya.
\end{abstract}

\begin{abstract}
The wise nation must think intelligently for the long term that the stick holder: of this nation relay are young children as generations of the nation's successors. The ethical and moral problem of the nation is the very fundamental problem of this dynasty. Overcome it through education through parents, teachers, the surrounding environment This research aims to describe the performance of the citizenship education teacher ir developing the character Ethics Association and Moral student in SMPN 5 of West Lombok sheet. The type of research used is qualitative research with a descriptive approach. Tht research subject is the teacher of PPKn, students of Class VII, principal, and teacher of BK. The data collection methods used are structured methods of observation, documentation, and interviews. Data analysis techniques used are qualitative descriptive through data reduction, data presentation, and withdrawal of conclusions. The results showed that the teacher's performance of citizenship education in building ethical and moral students of class VII in SMP Negeri 5 sheet is divided into four phases namely teacher readiness, application of curriculum learning model $K-13$, doing cooperation With parents, and give religious-spiritual learning through go and Duha prayers. And the factors that affect the teacher's performance in building ethical and moral students of class VII in SMP Negeri 5 datasheet are supporting factors, student attitude factors, family factors, environmenta factors, and other factors.
\end{abstract}

\section{A. LATAR BELAKANG}

Pendidikan merupakan kebutuhan manusia. Pendidikan selalu mengalami perubahan, perkembangan dan perbaikan sesuai dengan perkembangan di segala bidang kehidupan. Perubahan dan perbaikan dalam bidang pendidikan meliputi berbagai komponen yang terlibat di dalamnya baik itu pelaksanaan pendidikan di lapangan (kompetensi guru dan kualitas tenaga pendidik), mutu pendidik, perangkat kurikulum, sarana dan prasana pendidikan dan mutu menejemen pendidikan termasuk perubahan dalam metode dan strategi pembelajaran yang lebih inovatif. Upaya perubahan dan perbaikan tersebut bertujuan membawa kualitas pendidikan Indonesia lebih baik. 
Bangsa yang bijak harus berpikir cerdas untuk jangka panjang, kedepannya yang memegang Negara ini adalah anak-anak muda sebagai generasi penerus bangsa, oleh karena itu harus memperbaiki dan menyiapkan generasi penerus bangsa agar menjadi bangsa yang berpendidikan dan berkarakter. Anak sebagai generasi penerus bangsa yang diharapkan mampu bangkit, membangun dan mengembangkan bangsa demi mencapai segala cita-cita luhur bangsa. Sehingga anak harus memiliki nilai-nilai etika dan moral sebagai modal yang utama.

Kondisi masih jauhnya bangsa Indonesia dari citacita yang dituju terlihat dari merosotnya karakter yang dimiliki anak bangsa. Permasalahan etika dan moral anak bangsa menjadi permasalahan yang sangat mendasar dinegeri ini. Kualitas etika dan moral yang semakin rendah dari kondisi yang kecil hingga ke kondisi yang besar mengakibatkan terhambatnya kemajuan bangsa Indonesia dalam waktu yang cukup lama. Permasalahan etika dan moral yang rendah ini sangat banyak terjadi pada anak-anak yang seharusnya masih dalam masa perkembangan dan pertumbuhannya diisi dengan hal-hal positif sehingga melahirkan generasi penerus bangsa yang beradap dan yang mempunyai etika dan moralitas yang baik.

Menurut Pasal 33 [1] "Berkembangnya potensi peserta didik agar menjadi manusia yang beriman dan bertakwa kepada Tuhan Yang Maha Esa, berakhlak mulia, sehat, berilmu, cakap, kreatif, mandiri dan menjadi warga Negara yang demokratis serta bertanggung jawab" isi pasal di atas menegaskan bahwa pendidikan nasional Indonesia di harapkan dapat menjadikan insan yang cerdas dimaksudkan adalah cerdas, lahirnya generasi penerus yang unggul terlahir melalui pelaksanaan pendidikan nasional. Menjadi suatu bangsa berpredikat ganda, tidak hanya memerlukan pengembangan ilmu, keterampilan, dan teknologi tetapi juga memerlukan pengembangan aspek-aspek lainnya, seperti kepribadian etika dan moral. Semua itu dapat disebut dengan pengembangan pendidikan nilai. Permasalahan etika dan moral tersebut. Diharuskan adanya tindakan-tindakan untuk mengatasinya, jawaban yang yang paling kuat yaitu melalui pendidikan. Pendidikan melalui orang tua, guru, dan lingkungan sekitar. Dengan mengaktualisasikan nilai-nilai Pancasila dan spiritual keagamaan pada siswa diharapkan dapat mengembangkan etika dan moral untuk mewujudkan generasi-generasi yang dapat membawa bangsa kedepannya lebih baik.

Pada umumnya para orang tua siswa sangat setuju dengan peran guru dalam menyisipkan pendidikan nilai etika dan moral. Hal ini dapat dipahami bahwa tingkah laku anak manusia dikendalikan oleh aturan-aturan tertentu (regulated behavior). Dapat dikatakan bahwa peran guru di sekolah sangatlah penting dalam menentukan sejauh mana sikap siswa dalam bertingkah laku sebagai bagian dari masyarakat, apakah sesuai dengan norma yang berlaku di masyarakat atau tidak. Di sekolah sebagai pendidik atau pengajar, guru merupakan salah satu faktor penentu keberhasilan dalam upaya membina etika dan moral siswa. Sebagai pengajar dan pendidik guru harus memiliki kopetensi atau kemampuan yang sesuai dalam mengembangkan etika dan moral siswa.

Penanaman Kedisiplinan Pada Siswa Kelas III E Melalui Pelajaran PKn di SDIT IQRA' 2 Kota Bengkulu, Sudah cukup maskimal; (a) Rencana Pelaksanaan Pembelajaran (RPP) yang dibuat guru belum terdapat rumusan tujuan penanamanan disiplin. (b) Rencana Pelaksanaan Pembelajaran (RPP) yang dibuat guru belum terdapat rumusan indikator penanamanan disiplin[2]. Pembangunan karakter adalah usaha paling penting yang pernah diberikan kepada manusia. Pembangunan karakter adalah tujuan luar biasa dari sistem pendidikan yang benar. Jika bukan mendidik dan mengasuh anak-anak untuk perkembangan tabiat yang luhur, buat apakah system pendidikan itu, baik pendidikan dalam rumah tangga maupun pendidikan dalam sekolah, orang tua dan guru tetap sadar bahwa pembangunan tabiat yang agung adalah tugas mereka. Apabila dalam dunia pendidikan tidak dapat mengajarkan kepada siswa mengenai nilai-nilai etika dan moral yang baik maka akan bertemu dengan siswa yang cenderung bertindak kekerasan, pemaksaan kehendak, dan pelecehan niali-nilai kemanusiaan.

Berdasarkan obsevasi awal pada bulan Desember 2018 di SMPN 5 Lembar bahwa nilai etika dan moral di kalangan siswa sangatlah rendah seperti membolos, menyontek dan kurangnya kedisiplinan, berkurangnya rasa hormat terhadap orang tua dan guru sudah menjadi masalah yang sampai saat ini belum dapat diatasi secara tuntas. Hal inilah yang harus diperbaiki dan dibenahi di SMPN 5 Lembar untuk memberikan contoh teladan yang baik tentang dampak dari kenakalan remaja, dan memberikan bimbingan yang tepat guna yang dapat dijadikan filter atau penyaring oleh siswa untuk mengontrol diri dari adanya pengaruh-pengaruh negative dalam kehidupan sehari-hari. Selain itu kekuatan etika dan moral peserta didik untuk menjaga adab mereka mengahadapi kebobrokan etika dan moral yang sering terjadi. Dengan membina etika dan moral diharapkan siswa tidak hanya berfikir dengan benar tetapi juga bertindak dengan benar dan membentuk karakter yang kuat.

Berdasarkan uraian dari latar belakang di atas, maka yang menjadi rumusan masalah pada penelitian ini adalah bagaimana Kinerja Guru Pedidikan Kewarganegaraan dalam Membina Etika dan Moral Siswa Kelas VII di SMPN 5 Lembar, dan faktor apa yang mempengaruhi Kinerja Guru Pendidikan Kewarganegaraan dalam Membina Etika dan Moral Siswa Kelas VII SMPN 5 Lembar?. 


\section{B. METODE PENELITIAN}

\section{Metode Yang Digunakan}

Metode yang digunakan dalam penelitian ini adalah metode kualitatif dengan pendekatan deskriptif. Metode penelitian kualitatif adalah metode penelitian yang digunakan untuk meneliti pada kondisi obyek yang alamiah, (sebagai lawannya adalah eksprimen), dimana peneliti adalah sebagai instrumen kunci, tehnik pengumpulan data dilakukan secara triangulasi (gabungan), analisis data bersifat induktif, dan hasil penelitian kualitatif lebih menekankan makna dari pada generalisas [3]. Sedangkan pendekatan deskriptif digunakan untuk berupaya memecahkan atau menjawab permasalahan yang sedang dihadapi pada situasi sekarang. Dilakukan dengan menempuh langkahlangkah pengumpulan, klasifikasi, dan analisis/ pengolahan data, membuat kesimpulan dan laporan dengan tujuan utama untuk membuat gambaran tentang sesuatu keadaan secara objektif dalam suatu deskriptif situasi. Itulah sebabnya disebut dengan pendekatan deskriptif [4].

Alasan penulis menggunakan metode kualitatif deskriptif ini dikarenakan dalam penelitian data yang dihasilkan berupa data deskriptif yang diperoleh dari tulisan, kata-kata dan dokumen yang berasal dari sumber atau informasi yang diteliti dan dapat dipercaya serta untuk mendapatkan data yang mendalam dan menemukan apa yang tersembunyi nilai-nilai dibalik yang nampak.

\section{Lokasi Penelitian}

Penelitian ini akan dilaksanakan di SMPN 5 Lembar. Adapun alasan peneliti memilih SMPN 5 Lembar sebagai lokasi penelitian karena untuk mengamati dan meneliti bagaimana kinerja guru dalam membina etika dan moral siswa dan juga guna meningkatkan kualitas pendidikan yang ada di SMPN 5 Lembar tersebut, dalam kehidupan bermasyarakat, berbangsa, dan bernegara.

\section{Penentuan Subyek Penelitian}

Subyek penelitian merupakan sesuatu yang kedudukannya sangat sentral karena pada subyek penelitian itulah data tentang variabel yang diteliti berada dan diamati oleh peneliti [5]. Berdasarkan pendapat tersebut, maka yang menjadi subyek penelitian dalam penelitian ini adalah Guru, Kepala Sekolah, dan Siswa. Alasan guru menjadi subyek penelitian dan sumber informasi adalah untuk mendapatkan data-data yang lebih benar dan sesuai dengan yang terjadi di lapangan agar penelitian tidak mendapatkan data yang mengada-ngada, karena guru sangat penting untuk mengatur segala macam proses pembelajaran dalam meningkatkan etika dan moral siswa di SMPN 5 Lembar. Sehingga siswa mampu untuk menjadi manusia yang berpendidikan dan berpartisipasi dalam kehidupan bermasyarakat, berbangsa, dan bernegara.

Alasan memilih siswa sebagai subyek penelitian yang kedua adalah, untuk mendapatkan informasi lebih lanjut apakah guru melaksanakan pembinaan partisipasi untuk mendidik siswa sudah sampai mana kemampuan dan cara guru mendidik siswa dalam sekolah.

Alasan kepala sekolah sebagai subyek ketiga peneltian adalah, untuk mendapatkan informasi lebih lanjut terkait mendidik siswa di dalam lingkungan sekolah dengan seluruh guru-guru yang ada terutama dalam meningkatkan etika dan moral siswa.

Adapun tehnik sampling yang sering digunakan dalam penelitian kualitatif adalah tehnik purposive sampling dan snowball sampling. Sugiyono memberikan definisi kedua tehnik tersebut adalah sebagai berikut:

Purposive sampling adalah tehnik pengumpulan sampel sumber data dengan pertimbangan tertentu. Pertimbangan tertentu ini misalnya orang tersebut dianggap paling tau tentang apa yang kita harapkan, atau mungkin sebagai penguasa sehingga akan memudahkan penelitian menjelajahi obyek atau situasi sosial yang diteliti. Snowball sampling adalah teknik pengabilan sampel sumber data, yang pada awalnya jumlahnya sedikit, lama-lama menjadi besar[6].

Berdasarkan pendapat diatas, maka peneliti menggunakan teknik pengambilan sampel dengan tehnik sampel purposive sampling. Hal ini dilakukan karena informasi ini dianggap lebih mengetahui dan lebih faham terhadap masalah yang diteliti dan dapat memberikan data yang lebih lengkap dan tidak menggunakan istilah populasi.

\section{Metode Pengumpulan Data}

Teknik pengumpulan data merupakan langkah yang paling strategis dalam penelitian, karena tujuan utama dari penelitian adalah mendapatkan data.Teknik pengumpulan data adalah cara yang dapat digunakan oleh peneliti untuk mengumpulkan data. Secara umum terdapat empat macam tenik pengumpulan data, yaitu observasi, wawancara, dokumentasi, dan gabungan/trigulasi. Adapun teknik pengumpulan data yang digunakan peneliti dalam penelitian ini diantaranya adalah observasi, wawancara, dan dokumentasi.

\section{a) Metode Observasi}

Metode observasi biasa diartikan sebagai pengamatan dan pencatatan secara sistematik terhadap gejala yang tampak pada obyek penelitian. Gejala-gejala yang dimaksud adalah hal-hal yang berhubungan dengan. Kinerja guru dalam membina etika dan moral siswa obyek studi. Dari pengamatan inilah peneliti akan mencatat secara sistematis gejala-gejala yang muncul dipermukaan, baik didalam bentuk-bentuk kegiatan maupun hal-hal yang bersifat pembinaan. 
Nasution menyatakan bahwa observasi adalah dasar semua ilmu pengetahuan. Para ilmuan hanya dapat bekerja berdasarkan data. Yaitu fakta mengenai dunia kenyataan yang diperoleh melalui observasi[6][7].

Dengan menggunakan metode observasi ini peneliti bisa melihat bagaimana kinerja guru dengan efektif membina etika dan moral siswa dalam kehidupan bermasyarakat, berbangsa, dan bernegara.

\section{b) Metode Wawancara}

Metode wawancara digunakan untuk mendapatkan data tentang kinerja guru dalam membina etika dan moral siswa SMPN 5 Lembar. Wawancara harus dilakukan oleh peneliti kepada informan yang dapat dipertanggung jawabkan kebenarannya, seperti guru serta siswa SMPN 5 Lembar.

Esterberg mendefinisikan Wawancara adalah merupakan pertemuan dua orang untuk bertukar informasi dan ide melalui tanya jawab, sehingga dapat dikonstruksikan makna dalam suatu topik tertentu [8].

Esterberg dalam [8], mengemukakan beberapa macam wawancara yaitu.

1) Wawancara terstruktur, digunakan sebagai tehnik pengumpulan data, bila peneliti atau pengumpul data telah mengetahui dengan pasti tentang informasi apa yang akan diperoleh. Oleh karena itu dalam melakukan wawancara, pengumpulan data telah menyiapkan instrument penelitian berupa pertanyaan-pertanyaan tertulis yang alternatif jawabannya pun telah disiapkan.

2) Wawancara semiterstruktur, jenis wawancara ini termasuk dalam kategori in-dept interview, dimana dalam pelaksanaannya lebih bebas bila dibandingkan dengan wawancara terstruktur. Tujuan dari wawancara jenis ini adalah untuk menemukan permasalahan secara lebih terbuka.

3) Wawancara tidak terstruktur, adalah wawancara yang bebas dimana peneliti tidak menggunakan pedoman wawancara yang telah tersusun secara sistematis dan lengkap untuk pengumpulan datanya.

Adapun wawancara yang digunakan dalam penelitian ini adalah wawancara terstruktur. Maksud digunakan wawancara terstruktur dalam penelitian ini adalah untuk mendapatkan informasi awal tentang berbagai permasalahan yang ada pada obyek penelitian. Sehingga peneliti dapat menentukan secara pasti permasalahan yang diteliti. Teknik ini bertujuan untuk memperoleh informasi dan keterangan dari informasi yang berkaitang dengan masalah kinerja guru dalam membina etika dan moral siswa kelas VII SMPN 5 Lembar dan faktor yang mempengaruhi kenerja guru dalam membina etika dan moral siswa kelas VII SMPN 5 Lembar. Sesuai dengan subjek penelitian bahwa wawancara dilakukan kepada tiga subjek yaitu Kepala Sekolah, Guru Pendidikan Kewarganegaraan dan Guru BK. Metode ini bermanfaat bagi peneliti karena bisa menggali informasi tentang topik penelitian secara mendalam, bahkan bisa mengungkap hal-hal yang mungkin tidak terpikirkan oleh peneliti itu sendiri.

\section{c) Metode Dokumentasi}

Metode dokumentasi merupakan metode penelitian terakhir yang digunakan oleh peneliti dalam memperoleh data. Teknik dokumentasi ini merupakan teknik pendukung dari data primer yang diperoleh dari wawancara.

Dokumentasi hasil penelitian dari observasi atau wawancara, akan lebih kredibel/ dapat dipercaya kalau didukung oleh sejarah pribadi kehidupan dimasa kecil, sekolah, di masyarakat, dan autobiografi. Hasil penelitian akan semakin kredibel apabila didukung oleh foto-foto atau karya tulis akademik dan seni yang telah ada[6].

Manfaat metode ini, peneliti bisa memperoleh hasil dokumentasi dengan memperkuat apa yang telah diwawancara dan diamati. Jadi, di sini tidak ada dugaan mengada-ada data ketika disertai wujud nyata penelitian. Metode dokumentasi adalah metode terahir yang digunakan, dengan penelitian ini peneliti bisa mengkaji tentang kinerja guru Pendidikan Kewarganegaraan dalam membina etika dan moral siswa.

Dari hasil penelitian dokumentasi yang dilakukan peneliti di SMPN 5 Lembar maka peneliti memperoleh data tentang foto-foto, profil sekolah, dan sarana dan prasarana.

\section{Jenis dan Sumber Data 1) Jenis Data}

Jenis data dalam pelaksanaan penelitian dapat dibagi menjadi dua bagian pokok, yakni jenis data kualitatif dan kuantitatif. Data kualitatif adalah jenis data yang berbentuk kata, kalimat, skema, dan gambar. Sedangkan jenis data kuantitatif adalah data yang berupa angka-angka atau bilangan sesuai dengan bentuknya.

Adapun jenis data yang digunakan dalam penelitian ini adalah data kualitatif bukan data kuantitatif, karena tidak berhubungan dengan angka-angka namun dijelaskan dengan kata-kata atau kalimat.

\section{2) Sumber Data}

Bila dilihat dari sumber datanya, maka pengumpulan data dapat dilakukan dengan menggunakan sumber data primer dan sumber data skunder. Sumber data primer adalah sumber data yang langsung memberikan data pada pengumpulan data, sedangkan sumber data skunder merupakan sumber yang tidak langsung memberikan data kepada pengumpul data, misalnya lewat orang lain atau dokumen [8]. Sumber data primer dari penelitian ini adalah wawancara lansung yang dilakukan peneliti pada responden. Sedangkan untuk data sekunder diperoleh dari pencatatan dokumen dan yang ada di SMPN 5 Lembar maupun informasi yang berhubungan. Jadi dalam penelitian ini peneliti memakai kedua sumber data yaitu sumber data primer dan sumber data skunder. 


\section{Instrumen Penelitian}

Terdapat dua hal utama yang mempengaruhi kualitas hasil penelitian, yaituh kualitas instrumen penelitian dan kualitas pengumpulan data. Dalam penelitian kualitatif, yang menjadi instrument atau alat penelitian adalah peneliti itu sendiri. Alasannya ialah, segala sesuatunya belum mempunyai bentuk yang pasti, Masalah, fokus penelitian, prosedur penelitian, hipotesis yang digunakan bahkan hasil yang diharapkan itu semua tidak dapat ditentukan secara pasti dan jelas sebelumnya. Segala sesuatu masi perlu dikembangkan sepanjang penelitian itu. Dalam keadaan serba tidak pasti dan tidak jelas itu, tidak ada pilihan lain dan hal lain dan hanya peneliti itu sendiri sebagai satu-satunya alat yang dapat mencapainya [8].

\section{Teknik Analisa Data}

Dalam penelitian kualitatif, data diperoleh dari berbagai sumber dengan menggunakan teknik pengumpulan data yang bermacam-macam (tringulasi), dan dilakukan secara terus menerus sampai datanya jenuh. Bogdan mengatakan bahwa, analisis data adalah proses mencari dan menyusun secara sistematis data yang diperoleh dari hasil wawancara, catatan lapangan dan bahan-bahan lain, sehingga dapat muda dipahami dan temuannya dapat diinformasikan kepada orang lain. Analisis data dilakukan dengan mengorganisasikan data, menjabarkan ke dalam unit-unit, melakukan sintesa, menyusun ke dalam pola memilih mana yang penting dan yang akan dipelajari, dan membuat kesimpulan yang dapat diceritakan kepada orang lain [6]. Dengan proses analisis data dalam penelitian kualitatif dan peneliti menggunakan teknik deskriptif, maka dalam [6] ada tiga komponen dalam analisis data yaitu sebagai berikut:

a. Reduksi data adalah proses merangkum, memilih hal-hal yang pokok memfokuskan pada hal-hal yang penting dicari tema dan polanya. Dengan demikian data yang diriduksi akan memberikan gambaran yang lebih jelas dan mempermudah melakukan pengumpulan data. Untuk mereduksi data, peneliti membuat ringkasan kontak, pengembangan kategori, pengkodean, dan membuat catatan reflex yang bermaksud menajamkan menggolongkan, mengarahkan yang tidak berlaku. Kemudian mengorganisasikan sedemikian rupa sehingga kesimpulan yang tepat ini dilakukan terus menerus selama penelitian berlansung.

b. Penyajian data adalah merupakan sekumpulan informasi tersusun yang memberikan kemungkinan adanya penarikan kesimpulan dan penarikan tindakan. Dalam penellitian kualitatif, penyajian data bisa dilakukan dalam bentuk uraian singkat, bagan, hubungan antara kategori dan sejenisnya, yang paling sering digunakan untuk menyajikan data dalam penelitian kualitatif adalah dengan teks yang bersifat naratif. c. Verifikasi atau penarikan kesimpulan adalah upaya yang diperoleh selama pengumpulan data berlangsung. Kesimpulan dalam penelitian kualitatif merupakan temuan baru yang sebelumnya belum perna ada.

Berdasarkan pendapat di atas, maka peneliti diharapkan dapat menemukan temuan yang baru berdasarkan permasalahan yang diangkat peneliti.

\section{HASIL DAN PEMBAHASAN}

1. Kinerja Guru Dalam Membina Etika dan Moral Siswa Kelas VII SMP Negeri 5 Lembar

Seorang pendidik mempunyai adil pada proses pembentukan karakter. Guru memiliki makna “dipercaya dan dicontoh". Secara tidak langsung juga memberikan pendidikan karakter pada siswanya. Oleh karena itu, profil guru seharusnya memiliki sifat-sifat yang membawa siswa kearah karakter atau etika dan moral yang baik.

Makna di atas, dapat memberikan persepsi mengenai makna dari guru itu sendiri. Sebagai guru dituntut untuk professional memberikan makna bagi sarjana pendidikan yang akan menjadi penopang estafet mendidik anak bangsa untuk memberikan suatu realita contoh dari diri mereka. Jika etika dan moralnya buruk, maka buruk juga sikap guru di mata siswanya dan terkadang siswa menjadikan panutan dalam kehidupan sehari-hari untuk mencapai etika dan moral yang baik kepada siswa, sudah selayaknya guru yang professional mampu menkontruksikan kembali perencanaan pendidikan yang dilakukan pada siswa untuk mendapatkan apresiasi yang baik dari siswa. Maka terlebih dahulu guru membenahi etika dan moral mereka di hadapan siswa dan bukan menjadikan etika dan moral sebagai topeng. Karena jika etika dan moral hanya dijadikan sebagai topeng. Maka suatu saat etika dan moral buruk kembali dan merusak tatanan sebelumnya sehingga menjadikan topeng baik menjadi topeng buruk.

Kinerja guru dalam membina etika dan moral siswa penting untuk diperhatikan karena merupakan suatu cara yang digunakan untuk mengetahui bagaimana etika dan moral siswa ketika bergaul di lingkungan sekolah, keluarga, dan masyarakat dalam proses belajar di dalam kelas, siswa sudah mampu untuk memahami materi yang di ajarkan dan mampu untuk menerapkannya dalam kehidupan sehari-hari.

Hal ini dikuatkan dengan hasil wawancara dengan kepala SMP Negeri 5 Lembar bapak (K) melalui bantuan pedoman wawancara secara garis besar sebagai berikut:

"Berkaitan dengan kajian tentang kinerja guru pendidikan kewarganegaraan dalam membina etika dan moral siswa yaitu dengan menanamkan nilainilai ahlak luhur dengan mengerjakan sifat-sifat yang terpuji (takwa, disiplin, patuh, tanggung 
jawab, dan jujur) melalui teladan guru. Saya selalu memberikan contoh kepada guru-guru yang ada di SMP Negeri 5 Lembar dengan senantiasa mengajak guru-guru melakukan sholat duha, datang tepat waktu ke sekolah dan bertanggung jawab dalam setiap masalah, itu semua saya lakukan agar mereka sadar pentingnya untuk menanamkan nilai etika dan moral terhadap siswa"

Berdasarkan kutipan bapak (K) diatas. Guru harus sadar bahwa siswa yang datang ke sekolah telah mempelajari pendidikan etika dan moral di rumah dari keluarga dan masyarakat. Ini bermakna siswa telah mempunyai sikap, kepercayaan dan tibiat tentang etika dan moral yang dipelajari mereka dari pada berbagai sumber sebelum mereka ke sekolah. Guru juga harus sadar bahwa sekolah itu sendiri merupakan sumber pembelajaran etika dan moral secara tidak langsung. Suasana sosial di sekolah dan bagaimana guru-guru bertingkah laku akan memberikan pengaruh secara tidak langsung kepada pembelajaran etika dan moral siswa. Guru harus menerima hakikat bahwa nilai-nilai etika dan moral sudah tertanam dalam diri siswa. Guru haruslah bersedia untuk mengajar dengan mengambil kira pengetahuan dan pembelajaran etika dan moral yang ada. Guru dikehendaki mengembangkan etika dan moral siswa ini dan membimbing mereka semasa pengajaran dilaksanakan. Pendidikan disekolah digunakan untuk meningkatkan pengetahuan etika dan moral siswa ke arah mencapai kesuksesan untuk melahirkan individu yang beretika, bermoral, dan berakhlak tinggi.

Peneliti juga melakukan wawancara kepada ibu (PY) selaku guru pendidikan kewarganegaraan yang mengajar kelas VII SMP Negeri 5 Lembar. Menurut ibu (PY) kinerja guru dalam membina etika dan moral siswa yaitu:

"Di kelas yang dilakukan untuk membina etika dan moral siswa diberikan melalui pembelajaran dalam kelas, saya mengatur pembelajaran sedemikian rupa agar menarik siswa dengan berbagai macam metode. Model pembelajaran yang diterapkan di SMP Negeri 5 Lembar didasarkan pada kurikulum yang berlaku atau yang digunakan yaitu kurikulum $\mathrm{K}-13$, salah satu model pembelajaran yang diterapkan pada kurikulum ini adalah saintifik yang menekankan 5 item dalam proses pembelajaran yaitu dengan mengamati, menanya, menganalisis, mengasosiasi, dan mengkomunikasikan.”

Pernyataan diatas adalah upaya yang dilakukan ibu (PY) dalam membina etika dan moral siswa yaitu dengan kegiatan pembelajaran dikelas. Dengan begitu siswa akan lebih aktif dalam proses pembelajaran dan guru PKn akan lebih mudah untuk menanamkan dan membina etika dan moral siswa. Dalam kurikulum 2013 KI 1 yang membuat pembelajaran spiritual dan KI 2 tentang sosial (kejujuran, tanggung jawab, kerja sama dalam diskusi) sangat berpengaruh dalam membina etika dan moral siswa.

Kinerja yang dilakukan guru dalam membina etika dan moral siswa dalam kelas melalui pembelajaran menggunakan kurikulum K-13 model saintifik yang menekankan siswa lebih aktif dalam proses belajar mengajar. Dalam membina etika dan moral siswa yang dilakukan oleh guru PKn yaitu dengan cara mengajak siswa untuk melakukan do'a bersama sebelum pembelajaran akan dimulai, dan saat pelajaran memasuki sholat duhur maka guru mengajak siswa untuk sholat duhur berjama'ah[9][10]. Nilai etika dan moral yang disampaikan guru PKn telah terkandung dalam materi yang disampaikan. Guru PKn juga sering memberikan motivasi pada siswa melalui cerita tentang realita pergaulan sekarang dan dulu, menunjukan dampak negatif melakukan penyelewengan etika dan moral.

Guru haruslah bertanggung jawab menyalurkan nilai-nilai murni pendidikan etika dan moral di kalangan siswanya. Oleh karena itu, untuk mencapai pendidikan yang mampu menjadikan siswa yang memiliki etika dan moral yang baik, pelajaran-pelajaran sekolah akan diberi peluang menghayati nilai-nilai murni serta mengamalkannya dalam kehidupan mereka melalui kegiatan belajar mengajar secara langsung, antara moral dan etika sebenarnya tidak sama. Moral adalah hal yang mengatakan bagaimana kita hidup dan etika adalah usaha manusia untuk memakai akal budi dan daya pikirannya untuk memecahkan masalah bagaimana ia harus hidup kalau ia mau menjadi baik.

Peran guru sebagai model atau contoh bagi siswa. Setiap siswa mengharapkan guru mereka dapat menjadi contoh atau model baginya. Oleh karena itu tingkah laku pendidik baik guru, orang tua atau tokoh-tokoh masyarakat harus sesuai dengan norma-norma yang dianut oleh masyarakat, bangsa dan Negara. Peran guru di sekolah ditentukan oleh kedudukannya sebagai orang dewasa, sebagai pengajar dan pendidik dan sebagai pegawai yang paling utama ialah kedudukannya sebagai pengajar dan pendidik yakni sebagai guru. Berdasarkan kedudukannya sebagai guru ia harus menunjukkan kelakuan yang layak bagi guru menurut harapan masyarakat.

Pembinaan etika dan moral siswa melalui pembelajaran PKn kurang efektif, karena masih ada siswa yang keluar masuk saat kegiatan belajar mengajar berlangsung, selain itu siswa juga sering mengganggu siswa lain yang sedang serius belajar sehingga menimbulkan keributan dan kurang sopan terhadap guru yang sedang mengajar. tindakan siswa tersebut mencerminkan bahwa etika dan moral yang dimilikinya sangat tidak baik, oleh karena itu etika dan moral yang dimiliki siswa tergantung oleh siswa itu sendiri dan lingkungannya, sehingga jelas bahwa Kohlberg [11] memandang penalaran moral dan etika dari isi, maka sesuatu dikatakan baik buruk akan sangat tergantung 
pada lingkungan sosial budaya tertentu, sehingga sifatnya sangat relatif.

Upaya yang dilakukan guru dalam membina etika dan moral siswa yaitu guru membimbing langsung siswa dengan tujuan agar siswa mengerti dari hal baik dan buruk. Dan juga dengan diajarkan sholat duha dan dzuhur berjama'ah. Selain itu agar kebiasaan sholat secara berjama'ah dapat dilaksaakan tidak hanya ketika di sekolah, melainkan juga dapat dilaksanakan siswa di rumah dan kehidapan di masyarakat.

\section{Faktor yang Mempengaruhi Kinerja Guru dalam Membina Etika dan Moral Siswa Kelas VII SMP Negeri 5 Lembar}

\section{a. Faktor Pendukung}

Pada dasarnya kesadaran siswa sangat dibutuhkan, karena kesadaran akan pentingnya etika dan moral akan membawa siswa pada hal yang baik. Jika siswa sadar akan pentingnya nilai etika dan moral, maka siswa akan sadar hukum yang didapat jika melanggar tata tertib sekolah, siswa sebagai seorang pelajar sudah pasti bisa membedakan mana hal baik atau buruk, dan perbuatan yang diperbolehkan atau dilarang.

Menurut informasi bapak (K) selaku kepala sekolah, faktor yang mempengaruhi kinerja guru pendidikan kewarganegaraan dalam membina etika dan moral siswa dapat disimak sebagai berikut:

"Faktor yang mempengaruhi kinerja guru dalam membina etika dan moral siswa disini dapat kami tuturkan bahwa dibutuhkan faktor pendukung yang dimaksud disini adalah faktor-faktor yang keberadaannya turut mendukung dalam membina etika dan moral siswa seperti kesiapan anak dan fasilitas sarana dan prasarana yang lengkap. Tampa adanya kesiapan fasilitas sarana dan prasarana yang disediakan sekolah maka kegiatan apapun dalam membina etika dan moral siswa tidak akan berjalan dengan baik."

Kesiapan siswa yang dimaksud oleh bapak (K) adalah dari pribadi siswa yang memiliki kesadaran bahwa dalam proses pembelajaran yang disampaikan oleh guru sangat penting dalam membina etika dan moral dalam dirinya. Saling menghormati, jujur, dan disiplin dapat diciptakan suasana belajar yang hidup untuk lebih memahami inti dari pembelajaran yang disampaikan oleh guru. Fasilitas sarana dan prasarana dalam proses pembelajaran baik dalam kelas maupun diluar kelas dapat mempengaruhi etika dan moral siswa. Seperti adanya mushola yang digunakan setiap pagi untuk sholat duha dan penanaman nilai spiritual.

\section{b. Faktor Sikap Siswa}

Kepribadian dari siswa berbeda-beda inilah yang menjadi faktornya seperti masalah siswa baik dirumah maupun di sekolah, kemampuan siswa dalam menangkap pelajaran yang berbeda dan waktu pelajaran yang terbatas membuat guru tidak dapat menyampaikan materi secara maksimal. Guru harus bisa mempelajari setiap karakter yang dimiliki siswanya.

Faktor yang mempengaruhi kinerja guru dalam membina etika dan moral siswa dapat disimak melalui kutipan guru PKn ibu (PY) sebagai berikut:

"Saya selaku guru PKn sudah berupaya semaksimal mungkin dalam mendidik siswa akan tetapi upaya yang saya lakukan memiliki faktor seperti dalam proses pembelajaran berlangsung masih ada siswa yang keluar masuk kelas, ribut, dan bolos. Karena tidak semua siswa selalu bersikap baik di dalam kelas maupun di luar kelas.

Berdasarkan paparan dari ibu (PY), pengaruh dari sikap siswa yang tidak baik maka akan dapat mempengaruhi temannya yang baik. Baik saat proses pembelajaran berlangsung maupun di luar kelas. Hal itu sering terjadi karena sikap yang dimiliki siswa sangat tergantung dari lingkungan tempat mereka bergaul dan lingkungan keluarga.

\section{c. Faktor Keluarga}

Lingkungan keluarga sangat memiliki peran penting dalam diri siswa. Terutama dalam hal mendidik etika dan moral siswa, etika dan moral siswa di sekolah merupakan cermin dari etika dan moral siswa di rumah, jika siswa saat di rumah disiplin maka ketika di sekolah siswa juga disiplin, orang tua kurang memperhatikan dan kurang menanamkan etika dan moral pada siswa ketika ada di rumah secara tidak langsung akan mempengaruhi sikap siswa ketika berada di lingkungan sekolah dan masyarakat. Hal ini disebabkan karena didalam diri siswa tidak tertanam etika dan moral yang baik. Ketika siswa berada diluar sekolah menjadi tanggung jawab keluarga, oleh karena itu keluarga atau orang tua siswa harus memperhatikan dan menanamkan etika dan moral yang baik pada siswa.

Menurut guru Bk ibu (Y) faktor yang mempengaruhi kinerja guru dalam membina etika dan moral siswa sebagai berikut:

"Saya selaku guru BK harus selalu menjalin kerjasama dengan orang tua dalam melakukan pengawasan terhadap anak ketika di rumah, sehingga kalau ada anak yang melanggar dari peraturan sekolah, berbuat atau berkata tidak terpuji maka orang tua langsung memberi tahu. Karena keluarga yang bisa membimbing dan mengawasi anaknya secara maksimal."

Berdasarkan hasil wawancara dengan ibu (Y) dalam membina etika dan moral siswa berkaitan dengan kerjasama dengan orang tua yaitu guru melakukan hubungan langsung kepada orang tua, karena orang tualah yang lebih mengerti tentang keadaan siswa yang sebenarnya. Karena sebagian besar waktu dari siswa itu bukan disekolah melainkan di rumah. Jadi keluarga disini berperan sepenuhnya terhadap membina etika dan moral siswa dengan memberikan nasehat dan memantau setiap kegiatan anaknya di rumah. Tingkah 
laku siswa di sekolah tidak sepenuhnya sama dengan tingkah laku siswa ketika berada di rumah.

\section{d. Faktor Lingkungan}

Lingkungan merupakan tempat yang sering menjadi penghambat/ kendala dalam upaya membina etika dan moral pada siswa, karena lingkungan adalah tempat yang cukup berpengaruh dalam pergaulan siswa, siswa akan lebih mudah melakukan penyimpangan etika dan moral karena lingkungan pergaulan yang tidak baik. Lingkungan pergaulan akan rentang dalam mempengaruhi etika dan moral siswa, hal itu akan berdampak tidak baik dalam perkembangan siswa kelak.

Faktor yang mempengaruhi guru dalam membina etika dan moral siswa menurut bapak (Z) selaku kesiswaan di SMP Negeri 5 Lembar sebagai berikut:

"Pengaruh lingkungan terhadap membina etika dan moral siswa sangatlah penting karena sebagian waktu siswa berada dan bergaul di lingkungan baik itu lingkungan keluarga, sekolah, dan lingkungan masyarakat. Dari ketiga lingkungan ini akan memiliki sikap etika dan moralnya masing-masing tergantung dari siswa juga yang menanggapi keadaan di lingkungannya."

Menurut bapak (Z) dari beberapa faktor di atas, yang mempunyai pengaruh lingkungan dalam membina etika dan moral siswa yaitu lingkungan dimana anakanak dijaman sekarang semakin tidak terpantau dengan baik dengan siapa mereka bergaul di lingkungannya. Apabila dari individu siswa itu etika dan moralnya baik tapi lingkungannya tidak menanamkan etika dan moral yang baik maka anak tersebut juga akan ikut terpengaruh dari pergaulan lingkungan.

\section{SIMPULAN DAN SARAN}

Kinerja yang dilakukan guru dalam membina etika dan moral siswa kelas VII di SMP Negeri 5 Lembar terbagi menjadi empat yaitu kesiapan guru, penerapan model pembelajaran kurikulum K-13, melakukan kerjasama dengan orang tua, dan memberikan pembelajaran spiritual keagamaan melalui imtak. Terlihat dalam proses belajar mengajar seorang guru pendidikan kewarganegaraan dalam membina etika dan moral siswa, diawal masuk kelas guru PKn memberikan arahan untuk berdoa diawal dan diakhir pelajaran, bukan hanya diterapkan berdoa saja, akan tetapi siswa juga menghafal pancasila disetiap pelajaran $\mathrm{PKn}$ berlangsung disitulah dapat dilihat bagaimana seorang guru PKn menanamkan rasa cinta tanah air pada siswa. Peran guru disekolah ditentukan oleh kedudukannya sebagai orang dewasa, sebagai pengajar dan pendidik dan yang paling utama ialah kedudukannya sebagai pengajar dan pendidik yakni guru.

Faktor yang mempengaruhi kinerja guru dalam membina etika dan moral siswa kelas VII di SMP Negeri 5 Lembar ada lima faktor yaitu faktor pendukung, faktor sikap siswa, faktor keluarga, faktor lingkungan, dan faktor lainnya. Jadi disini seorang guru haruslah lebih memahami atau dalam bahasa gaulnya lebih peka terhadap karakter atau kepribadian siswa yang berbedabeda agar guru mudah dalam membina dan menanamkan nilai etika dan moral pada siswa disekolah.

Dari hasil penelitian yang diperoleh maka saran yang diberika peneliti sebagai masukan kinerja guru dalam membina etika dan moral siswa kelas VII di SMP Negeri 5 Lembar yaitu:

1. Kinerja guru dalam membina etika dan moral siswa, guru harus meningkatkan kualitas pembelajarannya, baik dalam kreatifitas maupun dalam metodenya. Karena peneliti berpendapat bahwa mempertahankan lebih berat dari pada mendapatkan.

2. Untuk faktor yang mempengaruhi kinerja guru dalam membina etika dan moral siswa pada faktor keluarga harus menggunakan cara dengan sebaikbaiknya agar keluarga bisa mengawasi siswa lebih baik dan dapat mengurangi permasalahan dalam proses pengawasan keluarga.

\section{DAFTAR PUSTAKA}

[1] R. Indonesia, "Undang-undang Republik Indonesia Nomor 20 tahun 2003 tentang Sistem Pendidikan Nasional," Jakarta Pemerintah Republik Indones., 2003.

[2] Y. Irwansyah, P. Djuwita, and W. Wurjinem, "Studi Deskriptif Kinerja Guru dalam Penanaman Kedisiplinan Pada Siswa Kelas Iii E Melalui Pelajaran PKn di Sdit Iqra'2 Kota Bengkulu." Universitas Bengkulu.

[3] Sugiyono, Metode Penelitian Pendidikan $R \& D$. Bandung: Alfabeta, 2017.

[4] A. Mohammad and M. Asrori, "Psikologi remaja perkembangan peserta didik," Jakarta Bumi Aksara, 2004.

[5] A. Suharsimi, "Prosedur Penelitian, Jakarta: PT," Rineka Cipta, p. 201:274, 2013.

[6] P. Sugiyono, Metode Penelitian Kuantitatif, Kualitatif, dan R\&D. 2013.

[7] M. Ali, Penelitian Kependidikan: Prosedur dan Strategi. Penerbit Angkasa, Bandung, 1982.

[8] Sugiyono, Metode Penelitian Pendidikan:(Pendekatan Kuantitatif, Kualitatif dan $R \& D$ ). Alfabeta, 2014.

[9] M. T. Ilahi and R. K. Ratri, Revitalisasi Pendidikan Berbasis Moral. Ar-Ruzz Media, 2012.

[10] N. Zuhriyah, "Pendidikan Moral dan Budi Pekerti dalam Perspektif Perubahan," Jakarta Bumi Aksara, 2008.

[11] J. Burhanudin, Ulama dan kekuasaan: Pergumulan elite politik muslim dalam sejarah Indonesia. NouraBooks, 2012. 
84 CIVICUS : Pendidikan-Penelitian-Pengabdian Pendidikan Pancasila dan Kewarganegaraan | Vol. 7, No. 2, September 2019 , hal $76-83$ 